Table 3. Effect of soil management and grass species used in a killed-sod planting system on trunk cross-sectional area of young peach trees.

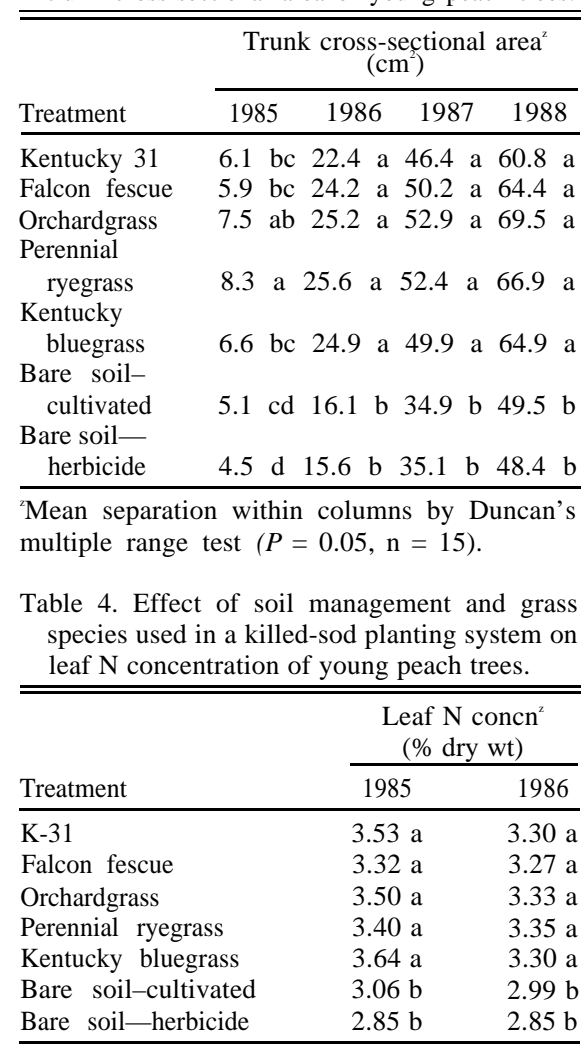

'Mean separation within columns by Duncan's multiple range test $(P=0.05, \mathrm{n}=15)$.

resulted in greater growth than the bare soil treatments through the third growing season.

It was not until the 4th year that the canopy width and tree height of those trees raised in bare soil equaled those raised in killed sod. TCA of trees grown in killed sod was greater at the end of 4 years than the TCA of trees grown in the bare soil treatments.

Leaf $\mathrm{N}$ levels were significantly higher during the first and second growing seasons in all the killed-sod treatments than in the bare soil treatments (Table 4). There were no differences between management systems after the second growing season (range 2.632.76 in 1987 and 3.21-3.44 in 1988). These results are similar to those in our previous studies with killed sod (Welker and Glenn, 1988). There were no differences in leaf $\mathrm{N}$ content among grass species treatments.

$\mathrm{K}-31$ was used exclusively in our previous studies (Glenn and Welker, 1989a, 1989b; Welker and Glenn, 1988) investigating the attributes of a killed-sod planting system. This study showed that K-31 was not unique in its ability to improve peach tree growth when used to develop a killed-sod mulch. All of the grasses used in this study resulted in greater growth of the young peach trees than the conventional bare soil system, although $\mathrm{K}-31$ resulted in the least growth response of the grasses tested.

\section{Literature Cited}

Ghadiri, H. and D. Payne. 1986. The risk of leaving the soil surface unprotected against falling rain. Soil and Tillage Res. 8:119-130.
Glenn, D.M. and W.V. Welker. 1989a. Orchard soil management systems influence rainfall infiltration. J. Amer. Soc. Hort. Sci. 114:10-14. Glenn, D.M. and W.V. Welker. 1989b. Cultural practices for enhanced growth of young peach trees. Amer. J. of Alternative Agr. 4:8-11.

Horowitz, W. (cd.). 1970. Official methods of analysis. 11th ed. Assn. Offic. Chem., Washington, D.C. p. 17-18

Welker, W.V. and D.M. Glenn. 1988. Growth response of young peach trees and changes in soil characteristics with sod and conventional planting systems. J. Amer. Soc. Hort. Sci. 113:652-656.

HORTSCIENCE 25(5):515-516. 1990.

\title{
Influence of Aluminum and Manganese on Rabbiteye Blueberries
}

\author{
James M. Spiers \\ U.S. Department of Agriculture, Agricultural Research Station, Small \\ Fruit Research Station, Poplarville, MS 39470
}

Additional index words. plant nutrition, Vaccinium ashei

Abstract. A sand culture study arranged in a $3 \times 3$ factorial was used to determine the influence of $\mathrm{Al}$ and $\mathrm{Mn}$ levels on leaf nutrient content and plant growth of 'Tifblue' rabbiteye blueberry (Vaccinium ashei Reade). Aluminum fertilization increased leaf Al content but did not affect plant vigor, leaf dry weight, or chlorosis. Manganese fertilization resulted in increased $\mathrm{Mn}$ in the leaves and a decrease in all growth parameters measured. The Al $\times$ Mn interactions were significant for Mn concentration in the leaves and vigor ratings. At the highest $\mathrm{Mn}$ fertilization rate, increasing $\mathrm{Al}$ fertilization had a synergistic influence on leaf Mn. Plant vigor at the highest Mn rate was lowest when no Al fertilizer was added. Increasing Al fertilization resulted in better plant vigor in plants grown with a high rate of Mn fertilization.

Rabbiteye blueberries are acidophilic plants that can accumulate high levels of $\mathrm{Mn}$ and Al (Korcak, 1988; Spiers, 1984). In field conditions, leaf levels of $\mathrm{Al}$ and $\mathrm{Mn}$ in $V$. angustifolium Ait. and V. myrtilloides Michx. were up to 110 and $1500 \mathrm{mg} \cdot \mathrm{kg}{ }^{-1}$ respectively (Trevett et al., 1968). Field-grown highbush blueberries (V. corymbosum L.) had high levels of leaf $\mathrm{Al}\left(445 \mathrm{mg} \cdot \mathrm{kg}^{-1}\right)$ and $\mathrm{Mn}$ (183 $\mathrm{mg} \cdot \mathrm{kg}^{-1}$ ) (Ballinger and Goldston, 1967). There was no evidence of reduced growth at these $\mathrm{Al}$ and $\mathrm{Mn}$ levels.

Aluminum in large amounts is toxic to plants and any stimulator effects of $\mathrm{Al}$ on the growth of Vaccinium and other calcifugous plants may be due to indirect effects associated with lowering soil $\mathrm{pH}$ (Pratt, 1973). Peterson et al. (1987) indicated high leaf Al levels (up to $317 \mathrm{mg} \cdot \mathrm{kg}^{-1}$ ) associated with aluminum sulfate fertilization may cause poor growth in rabbiteye blueberries. Excess Al and $\mathrm{Mn}$ induced visible $\mathrm{Mg}$ deficiency and reduced leaf $\mathrm{Mg}$ and $\mathrm{Ca}$ in norway spruce (Picea abies L.) seedlings (Hecht-Buchholz et al., 1987); however, no visible toxicity symptoms were observed in several blueberry species treated with high levels of $\mathrm{Al}$ and Mn (Korcak, 1988). In the same study, 'Tifblue' rabbiteye blueberry exhibited less growth under high $(1.7 \mathrm{mM}) \mathrm{Mn}$ and best growth with intermediate $(0.072 \mathrm{mM}) \mathrm{Mn}$ fertilization. The objective of this study was

Received for publication 30 Mar. 1989. The cost of publishing this paper was defrayed in part by the payment of page charges. Under postal regulations, this paper therefore must be hereby marked advertisement solely to indicate this fact. to determine main and interactive effects of $\mathrm{Al}$ and Mn fertilization on 'Tifblue' rabbiteye blueberry.

Two-year-old 'Tifblue' plants were potted in 1 1-liter containers of water-washed sand during February 1987. This study was conducted in a fiberglass shade house (20\% shade) under natural daylength and temperatures. Plants were grown for 1 month without fertilization, then from 15 Mar. until 15 May were fertilized uniformly with a complete nutrient solution and then pruned to a height of $\approx 10 \mathrm{~cm}$.

Beginning 15 June 1987, previously described nutrient solutions (Spiers, 1978) with differential $\mathrm{Al}$ and $\mathrm{Mn}$ concentrations were applied to the pots 5 days a week. Nitrogen was supplied as $\left(\mathrm{NH}_{4}\right)_{2} \mathrm{SO}_{4}$ and solution $\mathrm{pH}$ was adjusted to $5.5 \pm 0.2$ with $\mathrm{H}_{2} \mathrm{SO}_{4}$. All pots were leached with tap water followed by demineralized water twice weekly. Fertilizer treatments were: all combinations of $\mathrm{Al}(0,3.7$, and $37 \mathrm{mM})$ and $\mathrm{Mn}$ levels $(0$, 1.8 , and $18 \mathrm{mM})$ supplied as $\mathrm{Al}(\mathrm{OH})_{3}$ and $\mathrm{MnCl}_{4} \mathrm{H}_{2} \mathrm{O}$, respectively. The 3 x 3 factorial experiment was arranged in a randomized complete-block design with single plants as experimental units and five replications. On 23 Sept. 1987, plants were visually rated for vigor $(0=$ dead, $5=$ most vigorous $)$ and chlorosis $(1=$ most chlorosis, $5=$ no symptoms). Leaf numbers 4,5 , and 6 from the terminal of several branches were collected, dried $(60 \mathrm{C})$, finely ground, and analyzed by atomic absorption spectrophotometry (Mn) or colorimetry (Al) (Chapman and Pratt, 1978). Total growth (dry-weight basis) was determined by harvesting the new growth 
Table 1. Influence of Al and Mn fertilization levels on plant characteristics and elemental leaf content of 'Tifblue' rabbiteye blueberry.

\begin{tabular}{|c|c|c|c|c|c|c|}
\hline \multirow{2}{*}{$\begin{array}{l}\text { Element and } \\
\text { concn } \\
\text { (mM) }\end{array}$} & & \multirow[b]{2}{*}{ Vigor $^{2}$} & \multirow[b]{2}{*}{ Chlorosis ${ }^{y}$} & \multirow{2}{*}{$\begin{array}{l}\text { New growth } \\
\text { dry wt }(\mathrm{g})\end{array}$} & \multicolumn{2}{|c|}{$\begin{array}{c}\text { Leaf concn } \\
\left(\mathrm{mg} \cdot \mathrm{kg}^{-1}\right)\end{array}$} \\
\hline & & & & & $\mathrm{A} 1$ & $\mathrm{Mn}$ \\
\hline \multicolumn{7}{|l|}{$\mathrm{Al}$} \\
\hline 0 & & 4.5 & 4.2 & 52 & 51 & 609 \\
\hline 3.7 & & 4.9 & 4.6 & 55 & 58 & 763 \\
\hline 37.0 & & 4.7 & 3.8 & 55 & 63 & 971 \\
\hline Significance-linear & & NS & NS & NS & * & NS \\
\hline \multicolumn{7}{|l|}{$\mathrm{Mn}$} \\
\hline 0 & & 5.0 & 4.8 & 58 & 55 & 70 \\
\hline$\cdot 1.8$ & & 4.9 & 4.6 & 56 & 58 & 401 \\
\hline 18.0 & . & 4.3 & 3.2 & 48 & 60 & 1872 \\
\hline Significance-linear & ( & $* *$ & $* *$ & $*$ & NS & $* *$ \\
\hline Interaction & & ** & NS & NS & NS & * \\
\hline $\mathrm{Mn}$. & $\mathrm{Al}$ & & & & & \\
\hline 0 & 0.0 & 5.0 & & & & 74 \\
\hline 0 & 3.7 & 5.0 & & & & 61 \\
\hline 0 & 37.0 & 5.0 & & & & .75 \\
\hline 1.8 & 0.0 & 5.0 & & & & 423 \\
\hline 1.8 & 3.7 & 5.0 & & & & 389 \\
\hline 1.8 & 37.0 & 4.7 & & & & 491 \\
\hline 18.0 & 0.0 & 3.6 & & & & 1330 \\
\hline 18.0 & 3.7 & 4.8 & & & & 1893 \\
\hline 18.0 & 37.0 & 4.7 & & & & 2448 \\
\hline
\end{tabular}

${ }^{2} 5=$ highest vigor.

${ }^{\mathrm{y}} 5=$ no chlorosis

$\mathrm{NS}, * * *$ Nonsignificant or Significant at $\mathrm{P}=0.05$ or 0.01 , respectively. There were no significant quadratic effects.

(growth after pruning) and adding this to the weight of the leaf samples collected for analysis.

The $\mathrm{Al} \times \mathrm{Mn}$ interactions were significant for leaf Mn concentration and plant vigor ratings (Table 1 ). At the 0 and $1.8 \mathrm{~mm}$ levels of Mn fertilization, Al fertilization had no influence on $\mathrm{Mn}$ in the leaves. With $18 \mathrm{~mm}$ Mn fertilization rate, increasing $\mathrm{Al}$ fertilization had a synergistic influence on leaf $\mathrm{Mn}$. Plants treated with the highest levels of both $\mathrm{Al}$ and $\mathrm{Mn}$ had an average of $2448 \mathrm{mg} \cdot \mathrm{kg}^{-1}$ $\mathrm{Mn}$ in their leaves. Plant vigor was greatest at the two lower levels of Mn fertilization. At the highest level of Mn fertilization, however, plant vigor was lowest when no $\mathrm{Al}$ fertilizer was added. Increasing Al fertilization resulted in better plant vigor under the high rate of $\mathrm{Mn}$ fertilization.

Increasing $\mathrm{Al}$ fertilization levels resulted in a linear increase in leaf concentrations of Al but had no independent significant effects on Mn leaf content, vigor, or new growth (Table 1). From 0 to $37 \mathrm{mM} \mathrm{Al}$ fertilization, there was an increase of only $12 \mathrm{mg} \mathrm{Al} / \mathrm{kg}$ in the leaves. There was a negative $\left(r^{2}=\right.$ $-0.331, P=0.05)$ relationship between leaf $\mathrm{Al}$ concentration and new growth of plants, but this was independent of $\mathrm{Al}$ fertilization levels. Korcak (1988) found similar results using lower $(0.015 \mathrm{~mm}) \mathrm{Al}$ fertilization levels.

Manganese fertilization influenced all characteristics measured, except $\mathrm{Al}$ concentration in the leaves (Table 1). As Mn fertilization levels increased from 0 to $18 \mathrm{mM}$, there was a linear increase in leaf Mn content from $70 \mathrm{mg} \cdot \mathrm{kg}^{-1}$ to $1872 \mathrm{mg} \cdot \mathrm{kg}^{-1}$. Both $\mathrm{Mn}$ fertilization levels and resulting Mn leaf concentrations were negatively correlated with all plant growth measurements. More Mn fertilization (and $\mathrm{Mn}$ in leaves) resulted in less plant vigor, more chlorosis, and less new growth. Some of this effect may be due to an increase in the anion (Cl-) associated with $\mathrm{Mn}$ fertilization, since most $\mathrm{Al}-\mathrm{Cl}$ species usually are more toxic than $\mathrm{Al}-\mathrm{SO}_{4}$ species, but the use of $\left(\mathrm{NH}_{4}\right)_{2} \mathrm{SO}_{4}$ as a $\mathrm{N}$ source and $\mathrm{H}_{2} \mathrm{SO}_{4}$ to control solution $\mathrm{pH}$ would tend to buffer these effects.

Within the limits of this study, high levels of Mn fertilization and corresponding leaf Mn content resulted in decreased plant growth in rabbiteye blueberries. The determined effects of high levels of Mn appear to be reduced by Al fertilization.

\section{Literature Cited}

Ballinger, W.E. and E.F. Goldston. 1967. Nutritional survey of 'Wolcott' and 'Murphy' blueberries (Vaccinium corymbown L.) in eastern
North Carolina. N.C. Agr. Expt. Sta. Tech. Bul. 178. p. 28

Chapman, H.D. and P.F. Pratt. 1978. Methods of analysis for soils, plants, and water. Univ. of Calif., Publ. no. 4034. p. 70-72.

Hecht-Buchholz, C., C.A. Joins, and P. Keil. 1987. Effect of excess aluminum and manganese on Norway spruce seedlings as related to magnesium nutrition. J. Plant Nutr. 10:1103-1110.

Korcak, R.F. 1988. Response of blueberry species to excessive manganese. J. Amer. Soc. Hort. Sci. 113:189-193.

Peterson, D. V., C.A. Mullins, D.A. Lietzke, and D.E. Deyton. 1987. Effects of soil-applied elemental sulfur, aluminum sulfate, and sawdust on growth of rabbiteye blueberries. J. Amer. Soc. Hort. Sci. 112:612-616

Pratt, P.F. 1973. Aluminum, p. 3-12. In: H.D. Chapman (cd.). Diagnostic criteria for plants and soils. Quality Press, Abilenc, Texas.

Spiers, J.M. 1984. Influence of lime and sulfur soil additions on growth, yield, and leaf nutrient content of rabbiteye blueberry. J. Amer. Soc. Hort. Sci. 109:559-562.

Spiers, J.M. 1978. Effects of pH level and nitrogen source on elemental leaf content of 'Tifblue' rabbiteye blueberry. J. Amer. Soc. Hort. Sci. 103:705-708.

Trevett, M. F., P.N. Carpenter, and R.E. Durgin. 1968. A discussion of the effects of mineral nutrient interactions of foliar diagnosis in lowbush blueberries. Maine Agr. Expt. Sta. Bul. 665. 